\title{
Mission to the Middle East 2017: The Plight of the Displaced
}

\author{
Kevin Appleby
}

\section{Introduction}

From February 23, 2017 to March 6, 2017, His Eminence Roger Cardinal Mahony, archbishop emeritus of Los Angeles, California; His Excellency Silvano Tomasi, c.s., delegate secretary for the Holy See's Dicastery on Integral Human Development; and Kevin Appleby, senior director of international migration policy for the Center for Migration Studies of New York (CMS) and the Scalabrini International Migration Network (SIMN), joined in a mission to Lebanon, Jordan, Iraq, and Greece to examine the situation of refugees and the displaced in these states.

The visit came against the backdrop of several actions and events which could adversely impact these populations in the immediate, near, and long-term future: (1) the proposed reduction in the number of refugees to be admitted by the United States from 110,000 to 50,000 a year, including a 120-day shutdown of the US refugee program; (2) the one-year-old agreement between the European Union and Turkey to halt Syrian and other refugee groups from migrating to and entering Europe; (3) the ongoing war against the Islamic State of Iraq and Syria (ISIS), most notably in the fight for the city of Mosul and surrounding villages in northern Iraq; and (4) the ongoing persecution of religious minorities in the region, including Christian groups.

Overall, the delegation found that, despite heroic work by international nongovernmental organizations (NGOs) and agencies in the region, including refugee protection organizations, the humanitarian need of refugees and internally displaced persons (IDPs) far outweigh the support given to them by the international community. In fact, the world community appears to be withdrawing its support, rather than increasing it. ${ }^{1}$

The following findings and recommendations from the mission are based on the delegation's conversations with actors in the region, including refugees and displaced persons, care providers, representatives of the Catholic Church, their aid agencies, and United Nations (UN) officials.

\section{Findings}

Recent actions by the United States and the European Union to deny protection to refugees exacerbate the human suffering in the region and could contribute to its destabilization. The conflict in Syria has lasted six years and has produced close to five million refugees and seven million IDPs. ${ }^{2}$ Although negotiations to end the conflict have begun, those on the ground believe

1 Charlie Dunmore, “UN Chief Says Aid for Syrian Refugees Is in Global Interest," Relief Web, March 28, 2017, http:// reliefweb.int/report/jordan/un-chief-says-aid-syrian-refugees-global-interest.

2 "Syrian Regional Refugee Response," United Nations High Commissioner for Refugees (UNHCR), 2016, http://data. unhcr.org/syrianrefugees/regional.php. 
it will take several more years before the conflict is ended and refugees are able to return safely to their homes.

In the meantime, international support for refugees and displaced persons is waning, as evidenced by recent actions by the United States and the European Union to reduce protection for vulnerable Middle East populations. This proposed reduction in support is joined by an increase in xenophobia in developed nations and fearmongering by elected officials.

The proposed US reductions in resettlement slots and foreign aid and its impact. The new administration in the United States has proposed a 55 percent reduction in the number of resettlement slots for the remainder of fiscal year (FY) 2017, from 110,000 to 50,000, meaning that only 15,000 more refugees will be resettled nationwide until October 1,2017 . Under the previous administration, as many as 25,000 Syrians were approved for resettlement for FY 2017, the majority of whom will now be trapped indefinitely in dangerous situations.

The United Nations High Commissioner for Refugees (UNHCR) will be unable to fill the gap in resettlement slots for Syrians and other populations without the original US commitment, particularly for vulnerable cases, such as families and individuals in imminent danger, the disabled, the elderly, women and children. In FY 2016, UNHCR's regional office in Amman, for example, referred as many as 42,000 cases to the United States and Europe. This year, that number could drop by more than half. ${ }^{3}$

\section{A Reduced Commitment to Refugees}

In Amman, Jordan, Christian refugees from Mosul, Iraq, wait for their resettlement applications to the United States and Europe to be adjudicated and for the processing of their security clearances. Caritas Jordan provides the community with support. However, the refugees' wait to join their families in the United States, either in Detroit or California, has been extended. Their cases have been placed on hold because the administration has reduced the number of refugees that the United States will accept in FY 2017 and beyond. "I was ready to go to the US, but was told that we will not be going," one father said. "We have been waiting for two years, and now we have less hope."

"We are honest people," said another. "We are not terrorists."

Moreover, under the proposed FY 2018 US foreign assistance budget, support for the care of refugees - including in Lebanon, Jordan, and Turkey - could be cut by 28 percent or more. ${ }^{4}$ As the largest donor of humanitarian assistance for the region, exceeding \$5 billion USD over the past five years, such a severe cut would severely undermine the ability of the host countries and international agencies to meet the basic needs of the growing refugee population. It also could weaken the ability and commitment of Lebanon, Jordan, and Turkey to protect the large refugee populations in their countries, and could lead them to close their doors to future refugees or even send some back to danger.

EU-Turkey migration deal undermines protection for Syrian and other refugees in the region. To compound matters, while the one-year-old migration agreement between the European Union

3 Conversation with UNHCR regional office (Amman, Jordan), 2017.

4 Nahal Toosi and John Dawsey, "Critics Warn Trump That Gutting Foreign Aid Will Endanger US," POLITICO, March 16, 2017, http://www.politico.com/story/2017/03/trump-budget-state-department-usaid-foreign-aid-236129. 
and Turkey has virtually halted the flow of refugees across the Aegean Sea into Greece, the promise of increased resettlement of Syrian refugees out of Turkey has not come to fruition, as only about 4,000 have been resettled to Europe under the agreement in the first year. Moreover, of the three billion euros promised to Turkey to help the refugees, only about one-third has thus far been given.

As a result, and because Europe has not delivered on other promises to Turkey, President Erdogan has threatened to reopen its borders and allow refugees to reach Europe, which could prompt another refugee crisis at Europe's doorstep. ${ }^{5}$

In addition, as many as 62,375 refugees are stuck in Greece, unable to request asylum or join family in European nations. A plan to relocate as many as 66,000 refugees from Greece and Italy to Europe, agreed to by the European Union in September 2015, is inching forward, with only 13,000 from Greece moved to date. ${ }^{6}$ The refugees in Greece are housed in over 40 camps, with 45,903 on the mainland and about 16,472 in reception centers on the islands of Lesbos, Samos, and others. Of the refugees slated for relocation, 2,100 are unaccompanied or separated children. ${ }^{7}$

\section{A Tale of Two Syrian Families in Greece}

A Caritas shelter in Athens houses several Syrian families blocked from traveling to Europe to request asylum. One family with four children from Aleppo escaped the violence there and has been selected for relocation to Switzerland, where they will begin their new life. The other, from Damascus, came after the March 20 EU-Turkey agreement and is not eligible for the EU relocation program. Their house was bombed and the eldest daughter, now nine, was burnt in the explosion and needs surgery to repair her skin. There is hope that the family will be considered an emergency case and be accepted in Germany or Sweden, where the specialized operation can be performed. There is no guarantee, however, that they will be relocated.

Afghans and other overlooked populations, including Iraqis, Pakistanis, and Bangladeshis, are stuck in Greece, ineligible in most cases for relocation to another European country, absent applying for a lengthy family reunification program. Most are waiting for the asylum process to be completed, which, with appeals, can take several months or more. Afghans are kept at the old Athens airport and at Olympic venues like football, hockey, and baseball stadiums. ${ }^{8}$

In a report coinciding with the one-year anniversary of the EU-Turkey deal, several NGOs based in Greece criticized the treatment of asylum seekers stranded in Greece, citing substandard conditions and the absence of security in camps, the lack of due process for asylum, insufficient education for children, and inadequate medical conditions. ${ }^{9}$

5 “Erdogan Threatens to Scrap EU-Turkey Deal," BBC News, March 16, 2017, http://www.bbc.com/news/worldeurope-39294776.

6 Matthew Holehouse, "EU Quota Plan Forced against East European States' Wishes," Telegraph, September 23, 2015, http://www.telegraph.co.uk/news/worldnews/europe/11883024/Europe-ministers-agree-relocation-of120000-refugees-by-large-majority.html.

7 UNHCR, Regional Refugee and Migrant Response for Europe: January-December 2017 (Geneva: UNHCR, 2016), http://knowledge.unccd.int/sites/default/files/inline-files/RRMRPEurope-2017.pdf.

8 Liz Alderman, "At Greece's Camps, Trying to Recreate the Everyday," New York Times, March 2, 2017, https://www. nytimes.com/2017/03/02/world/europe/greece-refugees-camps-conditions-syria.html?_r=0.

9 "One-Year Stranded and What has Changed? An Update to the October 2016 Joint NGO Policy Brief on the Situation of Displaced Persons in Greece," Jesuit Refugee Service in Greece, March 2016, http://www.jrsellada.com/ en/one-year-stranded/. 
Human rights organizations have argued that the EU-Turkey agreement violates international law, while European leaders have hailed it as successful in managing migration and in saving lives. ${ }^{10}$

\section{Stranded at the Airport}

Old Elliniko Airport, once the transportation hub of Athens, is now a shelter for 2,000 Afghan refugees. They live in makeshift tents in the airport terminal, with only hanging tarps separating families. Signs indicating airline departures and arrivals hang above them. The Afghan community here has fled the Taliban in their home country and is blocked from entering nations in Europe. Many have applied for asylum in Greece, hoping they may then qualify for a family reunification program that would send them to Germany. One family was targeted by the Taliban, with the father recruited to fight with them and the grandfather who, having refused to join their ranks, was then killed by them. The father of another family was kidnapped by the Taliban and was released after a $\$ 6,000$ USD ransom was paid. The conditions at the airport are crowded, dirty, and insecure. Fights have broken out among its residents. The Greek government, along with several NGOs, are working together to have these families relocated to urban settings.

International assistance will need to be increased, as ISIS is driven out of Iraq and the displaced are encouraged to return to their homes. Along with increased humanitarian assistance, the United States and other nations will need to help Iraq to rebuild its infrastructure, but also to build trust between different ethnic and religious communities in cities formerly occupied by ISIS.

As Iraq continues to push to retake Mosul, hundreds of thousands of IDPs are pouring out of the city. About 250,000 have fled east Mosul, and UNHCR is expecting another 200,000 to flee west Mosul, which is densely populated. ${ }^{11}$ Recent airstrikes by US forces have caused additional concern about the number of civilian casualties and IDPs produced by the battle. ${ }^{12}$

UNHCR is preparing to shelter and feed this new outflow, in addition to the nearly 1.3 million IDPs in Iraq who eventually will return to their homes. The international NGO community is trying to fill other needs for the IDPs, such as psychosocial counseling, education, permanent housing, and livelihoods training. ${ }^{13}$

Moreover, ISIS has left ruins behind in the many cities and areas it has occupied - Ramadi, Anbar province, Fallujah, and Tikrit, to name a few, not to mention the devastation of Mosul and villages of the Nineveh Plains. To restore the infrastructure of Ramadi alone could cost at least $\$ 10$ billion USD, with the costs of reconstructing Mosul in the tens of billions. ${ }^{14}$

10 Kevin Appleby, “Dispatches from the Middle East: The European Union-Turkey Migration Agreement One Year Later: A Victory for Orderly Migration or a Violation of International Law and Protection?" Center for Migration Studies of New York (CMS), March 20, 2017, http://cmsny.org/dispatches-eu-turkey-oneyrlater/.

11 "As Mosul Displacement Continues, UNHCR Opens New Camps, Expands Appeal," UNHCR, March 17, 2016, http://www.unhcr.org/en-us/news/briefing/2017/3/58cb9f234/mosul-displacement-continues-unhcr-opens-newcamps-expands-appeal.html?query=mosul.

12 Michael R. Gordon, "U.S. 'Probably Had a Role in Mosul Deaths, Commander Says," New York Times, March 28, 2017, https://www.nytimes.com/2017/03/28/world/middleeast/iraq-american-airstrike-mosul.html?_r=0.

13 Kevin Appleby, "Dispatches from the Middle East: The Battle for Mosul: The Humanitarian Cost," CMS, March 6, 2017, http://cmsny.org/dispatches-battle-for-mosul/.

14 Matthew Schweitzer, "Beyond a Military Victory: Reconstructing Iraq after ISIS," IPI Global Observatory, January 17, 2017, https://theglobalobservatory.org/2017/01/isis-iraq-united-nations-reconstruction/. 


\section{Educating the Displaced}

Caritas Iraq operates numerous child centers in Kurdistan and northern parts of Iraq, providing activities and education to more than 2,000 children. ${ }^{15}$ Approved by the Iraqi government to operate, they fill an important need for children of the displaced, many of whom do not receive the same attention in other Iraqi schools, or cannot access them. The children remain full of hope and, when asked, expressed their desire to become teachers, astronauts, and doctors. "They are the future of Iraq," one teacher said.

Many of the IDPs will not return to their towns until security and basic services are restored, plus materials and funds are provided to help them restore their homes, many of which have been burned or destroyed. ${ }^{16}$ This need will be exacerbated as ISIS is driven out of Iraq, as several cities and towns will need aid to rebuild basic infrastructure and institutions, such as the local law enforcement and justice systems, transportation and utility services, and community support organizations.

Perhaps a deeper wound that would prevent Iraqis from returning is the mistrust that has been built between neighbors who supported ISIS and occupied the homes of persons - mostly minorities - who fled ISIS. ${ }^{17}$ Sunni Muslims who fled ISIS also are without a place to go, as they cannot relocate in central and southern Iraq or live in Kurdistan. A peace and reconciliation process, plus a justice commission, may be required to ensure that security comes to these cities and towns in the future.

\section{Calling Home}

Khaldoon left Mosul after the US invasion of Iraq, but his mother and two brothers and their families have remained in their house in west Mosul. The family has been able to keep its home, as ISIS does not seize homes that are considered "full." Khaldoon calls home periodically to check on his family, but, if caught by ISIS talking on their phone, his family could be killed. "My brother sometimes goes on the roof on one of the houses to make a call, as it is safer. Sometimes he needs to get rid of a phone he has spoken to me on, in case ISIS seizes it and finds the call. ISIS executed three persons recently for making phone calls to their families."

Religious minorities in the region deserve increased protection, which may include resettlement of the most vulnerable to third countries. Religious minorities in the region, including Christians, Yazidis, and in some cases, either Sunni or Shia Muslims, deserve protection. Resettlement to a third country would be part of the solution, but, in truth, this would only apply to a small group of the most vulnerable.

The preferred option for the majority of Christian and other minority religions is to be protected at home. ${ }^{18}$ Chaldean Catholic and other Christian leaders expressed a strong desire to remain in their "ancestral" lands, and not to be relocated or resettled in large numbers. Some leaders indicated that US favoritism toward resettling Christians over Muslims places them at greater risk because extremists may target them as allies with their enemies.

15 Nikki Gamer, "Education for Displaced Iraqi Children," Caritas Internationalis, August 7, 2015, http://www.caritas. org/2015/08/education-for-displaced-iraqi-children/.

16 Conversation with displaced persons (Erbil, Iraq), March 2017.

17 Conversation with displaced persons (Erbil, Iraq), March, 2017.

18 Kevin Appleby, "Dispatches from the Middle East: A Conversation with Bishop Antoine Audo, Chaldean Catholic bishop of Aleppo, Syria, on Syrian Refugees," CMS, February 26, 2017, http://cmsny.org/dispatches-antoine-audo/. 


\section{Escaping Danger}

The Dominican sisters worked and lived in the city of Qaraqosh, a city of 50,000 and the largest Christian city in Iraq, about 30 kilometers outside of Mosul. They operated a school and lived in the community, helping families in their neighborhood with basic necessities. On August 6, 2014, they were told that they had 30 minutes to evacuate, as ISIS was entering the city to the west. The peshmerga, the Kurdish military, had retreated. The sisters piled in a few cars and left with no time to spare at around 11 p.m. Although normally a 90-minute car trip, they did not arrive in Erbil until the next morning at 9 a.m. They hope to return to their Motherhouse, but will not do so until it is completely "secure." The city was taken back in October 2016. ISIS destroyed the city, including its Christian icons and symbols. "We will need to rebuild trust within the community; it will take some time," they said.

Yazidis have experienced the most persecution by ISIS. At least 5,000 have been killed by the extremist group and an untold number of women taken as sex slaves. One Yazidi man with six children living in an unfinished home in Kurdistan said that he would not go back to Sinjar, his home, without international protection.

Christians in the Nineveh Plain, north of Mosul, also were driven out of their homes and experienced violence at the hand of extremists. Other Christians have fled to other countries in the West or to Jordan. Of the 1.2 million Christians in Iraq before the US invasion, only 300,000 remain.

\section{A Christian Enclave, Trying to Rebuild}

The town of Teloskof, north of Mosul in the Nineveh Plain, looked like a ghost town. A Christian enclave, it was occupied by ISIS for a few weeks, until they were driven out by the peshmerga, the military of Kurdistan. Its residents are returning, but daily life is slow. Homes, businesses, and the local Catholic church received extensive damage during the battle. ISIS burned or destroyed many homes of the residents, while others are riddled with bullet holes or have collapsed. The spirit of the town remains, as the community recently celebrated Mass in the church, with hundreds in attendance. While the residents are now safe, it will take more than prayers to reconstruct the town and restore it to daily life.

Children, the innocent victims of conflict, continue to endure the most suffering and require special services and attention. As is often the case, children suffer the most from war and conflict and the resulting displacement. The sad and haunting picture of the little boy Alan Kurdi moved the world, but children from all over the region have suffered and died because of the conflicts in Syria and Iraq and without the proper attention of the international community.

The primary needs of children in all the countries are psychosocial support and primary education. Most children are traumatized from their experiences of violence and flight, and require intensive counseling to overcome them. Many lose time in their education, as they are unable to access education in countries of first asylum. While NGOs, particularly Caritas Internationalis, Catholic Relief Services, and Jesuit Refugee Services try to fill the gaps with their own schools and informal education programs, children still can fall behind in their cognitive and psychological development.

Within the Syrian refugee population, an estimated 1.2 million (23 percent) are children. ${ }^{19}$ At least

19 "Syrian Regional Refugee Response." 
three million Syrian children under six have known nothing but war, while two-thirds have either lost a loved one, had their homes bombed or shelled, or been injured. ${ }^{20}$

\section{Building Peace}

In southern Erbil, Kurdistan, Jesuit Refugee Services runs a school to provide supplemental education to children displaced by the conflict in Iraq. The children are taught conflict resolution skills, art, and other exercises in building life skills. One class, with students interested in acting, play out a conflict resolution scene, with a Christian and Muslim student working out a disagreement peacefully. Not far away, the Dominican sisters teach the children the basics of math and reading. The schools educate Muslim and Christian children together, in order to teach them to live with one another and to build peace.

The exploitation and abuse of foreign-born domestic workers is a chronic problem that must be addressed. An underreported issue in some of the countries is the prevalence of foreignborn domestic workers who are abused and exploited by homeowners. They are recruited by traffickers with the promise of jobs, and, upon arrival, are trapped in abusive domestic situations, with their travel documents and passports taken away from them. Many are forced to work long hours and are not paid sufficiently, if at all, for their time. Some are sexually abused.

In Lebanon, the problem is chronic, as homeowners who "employ" the women often are protected from prosecution under Lebanese laws, known as the kafala sponsorship system. Once a domestic worker is rescued from the situation, the homeowner easily finds another worker to work and abuse. Most of the workers come from Africa, including Ethiopia, Eritrea, or Sudan, but others come from other nations in the Middle East. ${ }^{21}$

\section{Providing Protection for the Exploited}

Caritas Lebanon, supported by Catholic Relief Services, runs a continuum of shelters for foreignborn domestic workers who have been abused and exploited by traffickers and homeowners, providing them with psychosocial and legal support. Most of the women come from Africa and were promised jobs, but then held in bondage. They are waiting for the homeowners to return their travel documents, pay their way back home and provide them with back pay, but their legal cases can take months, if not years. In the meantime, the same homeowners have replaced them with another victim, provided to them through a network of "recruiters," or labor traffickers.

\section{Recommendations}

The US Congress must maintain funding for overseas assistance to refugees and for the resettlement of 110,000 refugees per year. In order to pay for immigration enforcement and defense spending, the Trump administration has indicated its intention to reduce foreign assistance funding by almost 30 percent. This would not only severely impact the ability of the United States to provide help to allies in the Middle East who are hosting millions of refugees, but also to resettle its fair share of the refugee caseload, particularly vulnerable cases. Congress

20 Save the Children, Invisible Wounds: The Impact of Six Years of War on Syrian Children (London: Save the Children, 2017), http://www.savethechildren.org.uk/sites/default/files/images/Invisible_Wounds.pdf.

21 Justin Salhani, "Domestic Workers in Lebanon Are Killing Themselves to Escape Abuse," ThinkProgress, August 18, 2016, https://thinkprogress.org/worker-suicides-lebanon-bdad104db8b4. 
should ensure FY 2018 funding for refugee protection which at least equals FY 2017 levels, and should restore spending for the resettlement of 110,000 refugees in FY 2018. At a minimum, 75,000 refugees, many of whom have cleared the security process, can be resettled in FY 2017, meaning 35,000 can be brought to the United States by October $1 .^{22}$

The European Union must resettle more Syrian and other refugees from Turkey, regardless of the "one-for-one" agreement. Under the EU-Turkey agreement of a year ago, only 4,000 Syrians have been resettled to Europe from Turkey. This number must be increased, regardless of any one-for-one tradeoff - one person being returned for one being resettled. The effect of the EUTurkey agreement has been to deter would-be asylum seekers from migrating across the Aegean Sea to Greece. Thus, tens of thousands of Syrian refugees and others have refrained from seeking protection in Europe, leaving them stuck in Turkey and elsewhere, where many are vulnerable. In fact, only about 1,500 refugees have been returned to Turkey from Greece since the deal was struck a year ago. If the European Union and the United States do not accept more refugees from Turkey, another flow of refugees could migrate to Greece and other European nations, causing another crisis in the region.

Greece, with help from the European Union, must improve conditions for refugees and ensure that they obtain due process protections. One aspect of the agreement that has gone badly is the assumption that Greece would be able to support, house, and provide due process to as many as 60,000 asylum seekers stuck on the mainland or on Greek islands. According to NGOs in Greece, these requirements are not being met. Conditions in the camps are below standards, legal support for asylum seekers is not generally available, and social services - health, food security, and cash assistance - do not meet humanitarian standards.

The Greek government, with help from the European Union, must: (1) transfer refugees from substandard encampments to safe urban accommodations, where possible; (2) organize the movement of vulnerable cases, including family reunification, off the islands and to the mainland; (3) use detention as a last resort, with children never being detained; (4) ensure security in all camps; and (5) ensure that all unaccompanied children are assigned a trained and vetted guardian to support their access to safe accommodations and specialized services.

The European Union must assist Greece in ensuring that asylum seekers receive due process, including legal assistance, by: (1) deploying a sufficient number of well-trained asylum officers and lawyers to assist in the Greek asylum process; (2) ensuring that safe and legal pathways are available to those seeking international protection; (3) ensuring that legal assistance/aid is available for both the initial and appeal stages of the asylum process; (4) promoting training and language programs to facilitate the labor integration of refugees; (5) increasing the hiring and training of asylum adjudicators so they can accept family reunification and relocation applications; and (6) expanding the definition of family within the Dublin Regulation, so that extended and adult family members in need of protection can be included in the family reunification process.

22 A Hawaii federal court placed a restraining order on the Trump Administration's temporary ban on refugee resettlement, allowing refugees to continue to arrive in the US; Kimberly Bender, "Charlotte Diocese Continues to Receive Refugees While Travel Ban Is Blocked by Courts," America Magazine, April 5, 2017, http://www. americamagazine.org/politics-society/2017/04/05/charlotte-diocese-continues-receive-refugees-while-travelban-blocked; "Genocide of Yazidis by ISIL," Wikipedia, last modified April 2, 2017, https://en.wikipedia.org/wiki/ Genocide_of_Yazidis_by_ISIL. 
The global community, particularly the United States, must commit itself to the reconstruction, rehabilitation, and reconciliation of cities, towns, and villages occupied by ISIS in Iraq. The defeat of ISIS in Iraq does not mean the end of the obligation of the United States and other Western powers. Support will be needed to ensure that towns and cities destroyed by ISIS are made whole. Peace and reconciliation processes should be facilitated within communities, since trust has been eroded between Iraqis who were targeted by ISIS and those who supported them.

Tens of billions of US dollars will be needed to rehabilitate and reconstruct cities like Mosul, Fallujah, Ramadi, and others in the years ahead. In its initial FY 2018 budget proposal, the administration did not include reconstruction funding for Iraq, and it is not likely to fund peace and reconciliation efforts either. ${ }^{23}$ In these circumstances, the US Congress must appropriate at least some portion of the needed funds. Without this support, Iraq would remain unstable and the displaced will be reluctant to return to their homes. According to reports, the Trump administration has floated the idea of taking the money from the costs of Iraqi oil, which would be counterproductive in developing its economy. ${ }^{24}$

Religious freedom and protection for religious minorities in both Syria and Iraq should be a priority for the global community. The protection of Christians and other minorities in the region remains a crucially important need. The overarching solution is the end of conflict and the restoration of security for all religious minorities, including Muslim communities targeted by extremists. Christian leaders have stated uniformly that preservation of their communities in the region is the best alternative, so they can maintain their presence in the region over the long term. However, vulnerable persons who are unable to remain in the region because of religious persecution should be eligible for resettlement. Ironically, the Trump administration's reduction of the refugee ceiling from 110,000 to 50,000 over the next two years will naturally limit the worldwide resettlement opportunities available to religious minorities, including Christians.

Lebanon and other Middle Eastern nations should eliminate the trafficking industry in domestic workers within their borders and prosecute those who benefit from the trade. As mentioned, foreign-born domestic workers who are recruited to Middle Eastern countries often are abused and exploited by homeowners. Laws in many of the countries, particularly Lebanon, protect those who profit from this exploitation. These laws must be changed to ensure that these workers are not kept in bondage, are not abused, and are provided basic worker protections, including a living wage.

\section{Conclusion}

It is a crucial time in the Middle East, as countries which host refugees are under strain, Western nations are threatening to withdraw support from these countries, and the end of the conflict remains out of sight. Ideally, the global community will work to end the Syrian conflict expeditiously

23 Rowan Scarborough, "US Leaving Mosul Reconstruction to Iraq-Potentially Creating Opening for Iran," Washington Times, November 6, 2016, http://www.washingtontimes.com/news/2016/nov/6/us-leaving-mosulreconstruction-to-iraq-potentiall/.

24 "Trump Project for the Reconstruction of Iraq for Oil," Mawazine News, March 27, 2017, https://search4dinar. wordpress.com/2017/03/27/mawazine-news-trump-project-for-the-reconstruction-of-iraq-for-oil/. 
and to secure the region. Otherwise, millions will continue to live in perilous situations. ${ }^{25}$ The global Catholic community, including such agencies as Caritas Internationalis, Catholic Relief Services, Jesuit Refugee Services, and International Catholic Migration Commission work to fill gaps in protection and services in the Middle East and other places around the globe. ${ }^{26}$ However, Catholic service providers, international organizations, and other international nongovernmental groups can only respond to the human suffering caused by conflict, not rehabilitate and restore the many devastated towns and communities destroyed by it. The international community, led by the United States, must help achieve this goal.

The Global Compacts on Responsibility Sharing for Refugees and Safe, Regular, and Orderly Migration represent an important opportunity for the global community to commit to a humanitarian response to the large movements of refugees and migrants and away from a deterrence and enforcement approach. The Middle East, and particularly the conflict in Syria and Iraq, would benefit from a coordinated and shared approach to human displacement.

\section{Works Cited}

Alderman, Liz. 2017. "At Greece's Camps, Trying to Recreate the Everyday." New York Times, March 2. https://www.nytimes.com/2017/03/02/world/europe/greece-refugees-campsconditions-syria.html?_r=0.

Appleby, Kevin. 2017. "Dispatches from the Middle East: A Conversation with Bishop Antoine Audo, Chaldean Catholic bishop of Aleppo, Syria, on Syrian Refugees." New York: Center for Migration Studies of New York (CMS). http://cmsny.org/dispatches-antoine-audo/.

. 2017. "Dispatches from the Middle East: The Battle for Mosul: The Humanitarian Cost." New York: CMS. http://cmsny.org/dispatches-battle-for-mosul/.

.2017. "Dispatches from the Middle East: The European Union-Turkey Migration Agreement One Year Later: A Victory for Orderly Migration or a Violation of International Law and Protection?" New York: CMS. http://cmsny.org/dispatches-eu-turkey-oneyrlater/.

Bender, Kimberly. 2017. "Charlotte Diocese Continues to Receive Refugees While Travel Ban Is Blocked by Courts." America Magazine, April 5. http://www.americamagazine.org/ politics-society/2017/04/05/charlotte-diocese-continues-receive-refugees-while-travelban-blocked.

Dunmore, Charlie. 2017. "UN Chief Says Aid for Syrian Refugees Is in Global Interest." Relief Web, March 28. http://reliefweb.int/report/jordan/un-chief-says-aid-syrian-refugees-globalinterest.

25 On April 3, 2017, a chemical attack on civilians occurred in the town of Khan Sheikhoun in northern Syria, killing 87 people. "Syria Autopsies Show Chemical Weapons Used in Attack, Turkey Officials Say," Fox News, April 6, 2017, http://www.foxnews.com/world/2017/04/06/syria-autopsies-show-chemical-weapons-used-in-attack-turkeyofficials-say.html.

26 The delegation would like to thank Catholic Relief Services, Caritas Internationalis, Jesuit Refugee Services,the International Catholic Migration Commission, and the United Nations High Commissioner for Refugees for their assistance with the mission. 
“Erdogan Threatens to Scrap EU-Turkey Deal.” 2017. BBC News, March 16. http://www.bbc.com/ news/world-europe-39294776.

Gamer, Nikki. 2015. "Education for Displaced Iraqi Children." Caritas Internationalis. http://www. caritas.org/2015/08/education-for-displaced-iraqi-children/.

“Genocide of Yazidis by ISIL." 2017. Wikipedia. Last modified April 2. https://en.wikipedia.org/ wiki/Genocide_of_Yazidis_by_ISIL.

Gordon, Michael R. 2017. "U.S. 'Probably Had a Role in Mosul Deaths, Commander Says." New York Times, March 28. https://www.nytimes.com/2017/03/28/world/middleeast/iraqamerican-airstrike-mosul.html?_r=0.

Holehouse, Matthew.2015. “EU QuotaPlan ForcedagainstEastEuropean States' Wishes." Telegraph, September 23. http://www.telegraph.co.uk/news/worldnews/europe/11883024/ Europe-ministers-agree-relocation-of-120000-refugees-by-large-majority.html.

Jesuit Refugee Service in Greece. 2016. "One-Year Stranded and What has Changed? An Update to the October 2016 Joint NGO Policy Brief on the Situation of Displaced Persons in Greece." Athens: Jesuit Refugee Service in Greece. http://www.jrsellada.com/en/oneyear-stranded/.

Salhani, Justin. 2016. "Domestic Workers in Lebanon Are Killing Themselves to Escape Abuse." ThinkProgress, August $18 . \quad$ https://thinkprogress.org/worker-suicides-lebanonbdad104db8b4.

Save the Children. 2017. Invisible Wounds: The Impact of Six Years of War on Syrian Children. London: Save the Children. http://www.savethechildren.org.uk/sites/default/files/ images/Invisible_Wounds.pdf.

Scarborough, Rowan. 2016. "US Leaving Mosul Reconstruction to Iraq-Potentially Creating Opening for Iran." Washington Times, November 6. http://www.washingtontimes.com/ news/2016/nov/6/us-leaving-mosul-reconstruction-to-iraq-potentiall/.

Schweitzer, Matthew. 2017. "Beyond a Military Victory: Reconstructing Iraq after ISIS." IPI Global Observatory, January 17. https://theglobalobservatory.org/2017/01/isis-iraq-unitednations-reconstruction/.

"Syria Autopsies Show Chemical Weapons Used in Attack, Turkey Officials Say." 2017. Fox News, April 6. http://www.foxnews.com/world/2017/04/06/syria-autopsies-show-chemicalweapons-used-in-attack-turkey-officials-say.html.

Toosi, Nahal, and John Dawsey. 2017.“Critics Warn Trump That Gutting Foreign Aid Will Endanger US." POLITICO, March 16. http://www.politico.com/story/2017/03/trump-budget-statedepartment-usaid-foreign-aid-236129.

"Trump Project for the Reconstruction of Iraq for Oil." 2017. Mawazine News, March 27. https:// search4dinar.wordpress.com/2017/03/27/mawazine-news-trump-project-for-thereconstruction-of-iraq-for-oil/. 
UNHCR (United Nations High Commissioner for Refugees). 2016. “As Mosul Displacement Continues, UNHCR Opens New Camps, Expands Appeal." Geneva: UNHCR. http:// www.unhcr.org/en-us/news/briefing/2017/3/58cb9f234/mosul-displacementcontinues-unhcr-opens-new-camps-expands-appeal.html?query=mosul.

_. 2016. "Syrian Regional Refugee Response." Geneva: UNHCR. http://data.unhcr. org/syrianrefugees/regional.php.

- Regional Refugee and Migrant Response for Europe: January-December 2017. Geneva: UNHCR. http://knowledge.unccd.int/sites/default/files/inline-files/ RRMRPEurope-2017.pdf. 